\title{
ANALISIS PENGARUH BANTUAN SOSIAL LANGSUNG TUNAI (BST) TERHADAP POLA KONSUMSI MASYARAKAT SELAMA PANDEMI COVID-19
}

\author{
Rizki Febri Eka Pradani ${ }^{1}$, Imam Sarwani ${ }^{2}$, Ahmad Rauzyan Fikri ${ }^{3}$, Muhammad Firdaus ${ }^{4}$ \\ ${ }^{1}$ Universitas Nurul Jadid, febri@unuja.ac.id \\ ${ }^{2}$ Universitas Nurul Jadid, Imamsarwani24@gmail.com \\ ${ }^{3}$ Universitas Nurul Jadid, Rausyanbali@gmail.com \\ ${ }^{4}$ Universitas Nurul Jadid, phengkingers@gmail.com
}

DOI

https://doi.org/10.26740/jupe.v9n3.p121$\underline{128}$

\author{
Article history \\ Received \\ 30 June 2021 \\ Revised \\ 05 August 2021 \\ Accepted \\ 13 August 2021
}

\section{How to cite}

Pradani, R. F. E., Sarwani, I., Fikri, A. R., \& Firdaus, M. (2021). Analisis Pengaruh Bantuan Sosial Langsung Tunai (BST) Terhadap Pola Konsumsi Masyarakat Selama Pandemi Covid-19. Jurnal Pendidikan Ekonomi (JUPE), 9(3), 121128

https://doi.org/10.26740/jupe.v9n3.p121$\underline{128}$

Kata Kunci: Bantuan Sosial Tunai (BST), Pola Konsumsi

Keywords: direct subsidy, consumption patterns

Corresponding author

Rizki Febri Eka Pradani

febri@unuja.ac.id

\begin{abstract}
Abstrak
Bantuan Sosial Langsung Tunai (BST) merupakan salah satu dana bantuan dari pemerintah melalui kementerian sosial selama pandemi Covid-19 dengan tujuan untuk tetap menjaga daya beli dan konsumsi masyarakat terhadap kebutuhan pokok ketika pandemi wabah virus corona (Covid-19). Pemerintah berharap dengan adanya bantuan ini masyarakat dapat mengalokasikan dana bantuan sesuai dengan kebutuhan sehari-hari selama masa pandemi Covid-19. Tujuan dari penelitian ini adalah untuk menganalisis pola konsumsi masyarakat penerima (BST) selama pandemi di Desa Widoropayung Kabupaten Situbondo. Metode yang digunakan dalam penelitian ini menggunakan kualitatif dengan pendekatan fenomenologi. Teknik analisis menggunakan teknik triangulasi. Hasil penelitian menunjukkan bahwa pola konsumsi masyarakat ketika pandemi Covid-19 khususnya masyarakat Desa Widoropayung penerima BST cenderung menggunakan uang yang mereka dapatkan untuk konsumsi kebutuhan pokok sehari-hari dan mengkonsumsi kebutuhan penunjang selama pandemi Covid-19 seperti masker, jamu-jamuan.
\end{abstract}

Abstract
Bantuan Sosial Langsung Tunai (BST) is one of the aid funds from
the government through the Ministry of Social Affairs during the
Covid-19 pandemic with the aim of maintaining people's purchasing
power and consumption of basic needs during the coronavirus
(Covid-19) pandemic. The government hopes that with this
assistance, the community can allocate aid funds according to their
daily needs during the Covid-19 pandemic. The purpose of this study
was to analyze the consumption patterns of recipient communities
(BST) during the pandemic in Widoropayung Village, Situbondo
Regency. The method used in this study uses a qualitative approach
to phenomenology. The analysis technique uses triangulation
techniques. The results showed that the pattern of community
consumption during the Covid-19 pandemic, especially the people
of Widoropayung Village who received BST tended to use the
money they got to consume daily basic needs so that their immune
system was maintained and consume supporting needs during the
Covid-19 pandemic such as masks, herbal medicine.

\section{Abstract}

Bantuan Sosial Langsung Tunai (BST) is one of the aid funds from the government through the Ministry of Social Affairs during the Covid-19 pandemic with the aim of maintaining people's purchasing power and consumption of basic needs during the coronavirus (Covid-19) pandemic. The government hopes that with this assistance, the community can allocate aid funds according to their daily needs during the Covid-19 pandemic. The purpose of this study was to analyze the consumption patterns of recipient communities (BST) during the pandemic in Widoropayung Village, Situbondo Regency. The method used in this study uses a qualitative approach to phenomenology. The analysis technique uses triangulation techniques. The results showed that the pattern of community consumption during the Covid-19 pandemic, especially the people of Widoropayung Village who received BST tended to use the system was maintained and consume supporting needs during the Covid-19 pandemic such as masks, herbal medicine. 


\section{PENDAHULUAN}

Pandemi Covid-19 hampir melanda seluruh dunia tidak terkecuali Indonesia. Mulai dari akhir 2019 sampai memasuki tahun 2021 pandemi Covid-19 belum juga teratasi dengan baik. Corona Virus Desease 2019 atau yang sering kita kenal dengan Covid-19 adalah spesies virus yang menyebabkan penyakit mulai ringan hingga berat, seperti pilek dan penyakit serius seperti MERS dan $S A R S$. Virus ini dapat menular dari hewan ke manusia. Menularnyapun bisa terjadi dari manusia ke manusia. Sampai saat ini penularannya masih belum diketauhi secara pasti oleh tenaga medis. Banyak pendapat yang mengatakan bahwa penularan virus COVID-19 ini dari hewan ke manusia seperti kasus yang banyak muncul di Wuhan (Juaningsih, 2020). Penularan Covid-19 ini tergolong sangat cepat, sehingga organisasi kesehatan dunia World Health Organization (WHO) menyatakan darurat kesehatan masyarakat yang menjadi perhatian internasional untuk mengordinasikan tanggapan Internasional terhadap pandemi Covid-19. Kasus ini semakin hari semakin meningkat dengan jumlah kematian penduduk di dunia yang semakin meningkat pula dengan pesat sehingga WHO mengumumkan juga bahwa wabah ini sebagai Pandemic Global pada tanggal 11 Maret 2020 (Dong Y, 2020).

Jumlah penyebaran kasus Covid-19 yang menyerang penduduk di dunia sangat cepat dan menyebar ke negaranega di seluruh dunia tidak terkecuali Indonesia. Sampai bulan Agustus 2020 lalu, dilaporkan total keseluruhan kasus penduduk yang terkonfirmasi 17.660.523dengan 680.894 kematian dimana kasus ini dilaporkan di 216 negara di seluruh penjuru dunia (WHO, 2020), sedangkan untuk Indonesia kasus penduduk yang terkonfirmasi Covid-19 sebanyak 165.887 dengan 7.169 kematian yang tersebar di 34 provinsi yang ada di Indonesia (Kementerian, 2020).

Pandemi Covid -19 ini sangat berdampak terhadap sektor-sektor perekonomian global khususnya. Hal ini didukung dengan perekonomian Tiongkok yang juga terkena dampak dari pandemi ini. Tiongkok merupaka negara dengan pencapaian memiliki perokonomian terbesar ke dua di dunia. Negara ini mengalami perlambatan dalam bidang ekonomi akibat dari dampak pandemi Covid-19. Tahun 2019 pertumbuhan perekonomian di Tiongkok sebesar 6,1\% menjadi sekitar $3,8 \%$ pada tahun 2020. Pertumbuhan ekonomi Tiongkok akan bisa terus menurun mencapai $0,1 \%$ bahkan bisa mencapai angka minus jika pandemi Covid-19 tidak segera teratasi.

Mobilitas penduduk di dunia dalam menjalankan hidup terutama di sektor perekonomian yang begitu padat sehingga menjadi penyebab utama penyebaran virus
Covid-19. Lembaga riset kredibel di dunia memprediksi dampak-dampak negatif yang akan muncul terhadap ekonomi secara global yang akan mencekam dunia salah satunya Indonesia. Ekonomi Dunia diprediksi akan mengalami penurunan sampai dengan angka yang cukup dikatakan kritis yaitu -1,1\% di Tahun 2020 oleh JP Morgan. IMF memprediksi pretumbuhan ekonomi dunia mencapai angka -3\% akibat pandemi Covid-19 ini. Prediksi-prediksi ekonomi tersebut sangat menimbulkan kekhawatiran bagi penduduk di dunia (Iskandar, 2020). Sehingga setiap negara menerapkan peraturan-peraturan atau kebijakan untuk menjaga ketahanan dalam kehidupan masyarakat. Tidak hanya ketahanan pangan, ketahanan kesehatan yang menjadi sasaran utama pemerintah Indonesia saat ini.

Indonesia memberlakukan kebijakan-kebijakan salah satunya kebijakan dalam penanganan medis yaitu Pembatasan Sosial Berskala Besar (PSBB) disetiap daerah yang ada di Indonesia, hal ini berpengaruh pada sektorsektor perekonomian yaitu terputusnya mata rantai pasokan perekonomian sehingga terganggunya pasokan produksi dan konsumsi barang dan jasa yang ada di masyarakat husunya Indonesia (Misno, 2020).

Pemerintah Indonesia selain melakukan kebijakan untuk penanganan medis, pemerintah juga membuat berbagai macam program kebijakan dalam rangka menyelamatkan ketahanan pangan masyarakat hususnya di Indonesia dalam menanggulangi dampak pandemi Covid19 saat ini yang diharapkan mampu membantu perekonomian masyarakat secara langsung. Dana bantuan yang dislurkan pemerintah kepada masyarakat Indonesia diantaranya dalam berbagai bentuk bantuan yaitu uang tunai, penyaluran sembako, dan subsidi biaya tarif listrik serta menggratiskan tarif listrik dan lain sebagainya dimana pada kondisi pandemi seperti ini sangat dibutuhkan oleh masyraakat Indonesia yang terdampak pandemi Covid-19. Penyaluran bantuan ini diharapkan dapat mencukupi kebutuhan sehari-hari terutama kebutuhan-kebutuhan pangan masyarakat. Tujuan utama bantuan-bantuan dari pemerintah tersebut adalah untuk menjamin ketersediaan kebutuhan pokok masyarakat sebagai kebutuhan dasar masryarakat Indonesia contohnya membeli beras yang menjadi makanan pokok masyarakat Indonesia dan perlindungan sosial yang diutamakan bagi kelompok rentan terdampak pandemi Covid-19.. Kelompok rentan tersebut diantaranya adalah para pekerja/karyawan/buruh yang tidak menentu dalam hal kontrak, jam kerja, dan jaminan kesejahteraan (Arika Bagus P et.al, 2020).

Meningkatnya karyawan yang di PHK pada saat pandemi Covid-19 di Indonesia akan meningkatkan jumlah kelompok rentan di Indonesia khusunya. Sebelum terjadi pandemi Covid-19 pemerintah telah memberikan bantuan kepada masyarakat rentan. Namun semenjak pandemic Covid-19 ini pemerintah mengeluarkan dana 
bantuan sosial khusus. Dana bantuan sosial khusus ini penting untuk disalurkan karena meningkatnya pekerja informal yang mengalami penurunan pendapatan sangat drastic ketika pandemi bahkan sampai kehilangan pendapatannya akibat kebijakan pemerintah yang ada seperti kebijakan PSBB, WFH yang semakin menambah kelompok masyarakat rentan di Indonesia akibat dari banyaknya perusahaan yang melakuka pemutusan hubungan kerja (PHK) karyawannya (Lestary J. Barany et al, 2020, 3) serta penurunan daya beli masyarakat dan konsumsi masyarakat terhadap pemenuhan kebutuhan pokok setiap harinya. Kebutuhan masyarakat tidak akan berhenti meskipun adanya pandemi Covid -19. Banyak tokoh berasumsi ketika pandemi terjadi kebutuhan masyarakat bertambah dalam hal ketahanan melawan pandemi Covid-19.

Pada kondisi tertentu, seseorang atau masyarakat memiliki macam-macam kebutuhan yang tidak memiliki nilai urgensi yang baik untuk menciptakan motivasi untuk bertindak, sementara ada orang lain yang termotivasi untuk bertindak dalam keadaan tersebut (Hutauruk, 2020). Kekuatan yang dapat menciptakan rasa mendesak serta motivasi salah satunya adalah faktor internal, contohnya orang merasakan lapar, dan lingkungan contohnya pada saat pandemi Covid-19 masyarakat dituntut untuk melakukan protokol kesehatan diantaranya memakai masker dan menggunakan handsanitizer. Motiviasi dapat muncul ketika kebutuhan yang tidak terpenuhi, seperti halnya semua pemecahan dalam masalah konsumen. Teori A. H. Maslow tentang motivasi merupakan salah satu teori yang paling terkenal. Teori tersebut sering dikenal sebagai hierarki kebutuhan. Beliau mengembangkan model yang menjabarkan lima tingkat kebutuhan manusia yang berbeda satu sama lain. Macam-macam kebutuhan tersebut sangat berhubungan "hierarki kebutuhan", dengan kebutahan dasar yang berorientasi pada kelangsungan hidup di tingkat bawah hirarki, membangun kebutuhan emosional yang lebih tinggi yang terkait harga diri, cinta, dan pemenuhan diri (Huitt, 2007)

Dikutip dari website resmi Sekretariat Kabinet Republik Indonesia, Pemerintah Indonesia telah menyususn berbagai program bantuan diantaranya: Penyaluran PKH (Program Keluarga Harapan) kepada 10 juta KK dengan total anggaran dana sebesar Rp. 37,4 Triliun, Penyaluran Kartu sembako kepada 20 juta penerima yang setiap orang mendapatkan dana tersebut sebesar Rp. 200.000/bulan, penerbitan kartu prakerja kepada 5,6 juta orang dengan memberikan/mencairkan insentif sebesar Rp. 600.000 selama 4 bulan setelah mengikuti pelatihan yang dilakukan oleh pemerintah., Pemberian subsidi tarif listrik kepada pemakai daya 900 VA dan memberikan pembebasan tariff listrik untuk masyakat pengguna daya $450 \mathrm{VA}$, bantuan sosial yang ada
3 bantuan (bantuan bahan pokok sembako, Bantuan Sosial Langsung Tunai (BST), dengan nominal bantuan tersebut sama yaitu Rp. 600.000 dan disalurkan selama 3 bulan dan akan diperpanjang selama pandemi Covid-19. Macam bantuan yang lain adalah pengalokasian dana desa untuk bantuan sosial masyarakat desa selama 3 bulan sebesar Rp.600.000/bulan untuk 10 juta KK.

Dari berbagai macam bentuk bantuan dari pemerintah tersebut, penulis fokus meneliti mengenai jenis bantuan BST yang awalnya bernilai Rp. 600.000 menjadi Rp 300.000 dan akan disalurkan selama 3 bulan dari pemerintah melalui PT POS Indonesia. Kota/Kabupaten yang menjadi sasaran salah satunya Kabupaten Situbondo. Desa Widoropayung salah satu desa yang mendapatkan dana bantuan tersebut untuk warganya dengan syarat dan ketentuan yang sudah diatur oleh pemerintah agar tepat sasaran.. syarat utama masyarakat penerima BST adalah masyarakat yang bukan penerima bantuan sosial lainnya seperti PKH, bantuan sosial sembako dan terdampak adanya pandemi Covid-19. Penyaluran bantuan di Desa Widoropayung sudah berjalan selama kurang lebih 3 bulan dari tahun 2020-2021. Dalam hal ini warga penerima BST sudah merasakan efek dari bantuan yang mereka dapatkan tersebut.

Rumusan masalah yang didapat oleh penulis dari permasalahan diatas yaitu: Bagaimana pelaksanaan dana bantuan sosial langsung tunai (BST) mempengaruhi pola konsumsi masyarakat penerima dana bantuan BST di Desa widoropayung Kecamatan Besuki selama pandemi Covid19. Dari hal ini penulis juga memiliki tujuan dari pelaksanaan penelitian ini yaitu untuk mengetahui pengaruh dana bantuan BST terhadap pola konsumsi masyarakat Desa Widoropayung penerima BST pada masa pandemi Covid-19.

\section{METODE}

Metode yang digunakan dalam penelitian ini menggunakan kualitatif dengan pendekatan fenomenologi. Peneliti melakukan analisis secara mendalam terhadap objek penelitian yaitu Masyarakat Desa Widoropayung Kecamatan Besuki penerima dana bantuan BST. Tahapan yang pertama adalah melakukan observasi awal guna mengetahui gambaran secara umum mengenai dana BST terhadap masyarakat. Selanjutnya adalah tahap mereduksi data dimana dalam tahap ini peneliti memilihih data dan memfokuskan permasalahan-permasalah yang telah ditemukan di lapangan. Setelah tahap reduksi, tahap selanjutnya adalah tahapan seleksi yang menguraikan fokus permasalah mengenai pengaruh dana BST terhadap pola konsumsi masyarakat penerima dana BST di Desa Widoropayung. Langkah selanjutnya kemudian adalah analisis data yang menggunakan tekhnik triangulasi dan menyimpulkan hasil dari penelitian yang telah dilakukan. 
Teknik triangulasi yang digunakan ini bertujuan untuk memeriksa keabsahan data yang telah didapatkan dari berbagai sumber dengan berbagai cara dan waktu. Sehingga keabsahan data yang didapatkan baik.

Teknik penentuan responden adalah purposive sampling. Responden pertama yaitu Kepala Desa Widoropayung Kecamatan Besuki Kabupaten Situbondo, 10 orang masyarakat Desa Widoropayung penerima dana BST dari pemerintah melalui POS, 3 pedagang sembako di Desa Widoropayung.

Teknik pengumpulan data adalah menggunakan observasi, wawancara tidak terstruktur, dan yang terakhir adalah dokumentasi dengan cara memilih arsip yang berkaitan serta menunjang penelitian.

\section{HASIL DAN PEMBAHASAN Profil Desa Widoropayung}

Desa Widoropayung terletak pada Kecamatan Besuki Kabupaten Situbondo Provinsi Jawa Timur. Batas desa sebelah utara berbatasan dengan Desa Jetis, sebelah Selatan berbatasan dengan Desa Sumber Malang Kecamatan Jatibanteng, sebelah Timur berbatasan dengan Desa Gunung Malang Kecamatan Suboh, sebelah barat berbatasan dengan Kecamatan Jatibanteng. Desa Widoropayung memiliki jumlah penduduk sebesar 4.737 jiwa, 2.324 jiwa berjenis kelamin laki-laki, 2.413 jiwa berjenis kelamin perempuan. Mata pencaharian masyarakat widoropayung mayoritas sebagai petani dan buruh tani, ada pula masyarakat yang memiliki pekerjaan sebagai buruh bangunan dengan penghasilan rata-rata Rp 50.000/hari. Hal ini didukung dengan sebagian besar daerah Desa Widoropayung adalah area persawahan.

Rata-rata pendapatan masyarakat Widoropayung masih tergolong rendah yaitu sekitar Rp 35.000/hari. Desa Widoropayung memiliki 4 dusun, yaitu Dusun Sekolahan, Dusun Krajan, Dusun Tunjang, Dusun Gunung Mas. Sebaran masyarakat penerima BST Pos tiap dusunnya berbeda sesuai kriteria yang sudah ditentukan oleh pemerintah. Sebaran masyarakat penerima BST adalah sebagai berikut:

Tabel 1. Data masyarakat penerima BST per dusun

\begin{tabular}{llc}
\hline No. & Nama Dusun & Jumlah \\
\hline 1. & Dusun Krajan & 33 \\
2. & Dusun Tunjang & 9 \\
3. & Dusun Sekolahan & 14 \\
4. & Dusun Gunung Mas & 15 \\
\hline & Jumlah & 71 \\
\hline
\end{tabular}

Konsumsi Untuk Bertahan Hidup di Saat Pandemi Covid-19
Konsumsi adalah kegiatan yang dilakukan oleh manusia setiap harinya untuk memenuhi kebutuhan dalam keberlangsungan hidupnya. Konsumsi dalam hal ini bisa berupa barang dan jasa. Konsumsi dalam hal barang ini mulai dari kebutuhan primer, tersier, dan sekunder. Tidak semua orang bisa memenuhi ketiga kebutuhan tersebut. Konsumsi merupakan suatu kegiatan masyarakat yang dapat dipengaruhi oleh faktor pendapatan, lingkungan dan kebutuhan (Larasati, 2020).

Salah satu penyebabnya ketika adanya wabah Virus Corona atau sering kita sebut sebagai Covid-19. Pandemi Covid-19 ini berdampak pada sektor perekonomian tidak terkecuali perekonomian masyarakat Desa Widoropayung dimana banyak masyarakat menagalami penurunan pendapatan ataupun sampai kehilangan pendapatan akibat dari peraturan pemerintah dalam menanggulangi Covid-19 agar penularan virus tersebut tidak meraja lela, sehingga konsumsi masyarakat dalam pemenuhan hidup rendah namun adanya virus ini menuntut masyarakat untuk meningkatkan konsumsi pada kebutuhan primernya dalam hal ini makanan yang bergizi untuk meningkatkan imunitas tubuh sehingga bisa memproteksi diri kita terhadap virus Covid-19, semakin bermacam-macam makanan yang dikonsumsi oleh masyarakat maka akan meningktkan sumber gizi yang akan didapatkan dari pangan yang dikonsumsi (Saragih \& Saragih, 2020) tidak hanya itu keadaan lingkungan pada masa pandemi ini juga menuntut masyarakat untuk mengkonsumsi sesuatu yang tidak biasa dilakukan seperti pembelian masker dan handsanitizer.

Peran pemerintah dalam menangani dampak Pandemi Covid-19 yang terjadi di Indonesia adalah memberikan berbagai macam bantuan diantaranya BST yang disalurkan melalui PT.POS Indonesia. Penerima BST ini merupakan masyarakat sesuai dengan kriteria yang telah ditetapkan pemerintah salah satunya adalah masyarakat yang tidak menerima bantuan apapun dari pemerintah. Penerima BST ini memiliki penghasilan yang tidak besar terkadang tidak memiliki peghasilan sama sekali per harinya, dikarenakan tidak selalu mendapatkan pekerjaan pada masa pandemi ini. Pekerjaan masyarakat penerima BST ini bervariasi diantaranya buruh tani, buruh bangunan, pedagang kecil di pasar dan tukang ojek.

Masyarakat penerima BST memiliki kondisi ekonomi yang dapat dikatakan sangat terdampak oleh adanya pandemi Covid-19. Penerima BST memiliki jumlah tanggungan keluarga yang setiap harinya butuh sokongan finansial dalam pemenuhan hidup di saat pandemi. Fenomena ini menambah beban keluarga sehingga dirasa semakin sulit memenuhi kebutuhan pokok keluarga pada saat terjadi pandemi Covid-19.

Untuk memenuhi kebutuhan pokok setiap harinya masyarakat penerima BST yang disalurkan oleh POS Indonesia melakukan bermacam-macam cara atau memiliki pola konsumsi yang berbeda, hal ini disebabkan 
setiap penerima bantuan memiliki kondisi yang tidak sama sehingga memiliki pola konsumsi yang berbeda pula pada setiap keluarga.

Pola konsumsi dapat dijadikan sbagai salah satu indikator pengukur kesejahteraan rumah tangga. Masyarakat dengan kesejahteraan yang tergolong rendah memiliki pola konsumsi yang hanya terfokus pada pengeluaran makanan pokok. Seballiknya pola konsumsi masyarakat yang lebih sejahtera, didominasi pada pengeluaran non-makanan. Hal ini dikarenakan rumah tangga yang berpendapatan rendah fokus utamanya hanya memenuhi kebutuhan pokok demi keberlangsungan hidup rumah tangga setiap harinya sehingga pola konsumsinya dominan pada konsums makanan pokok. Sedangkan rumah tangga yang memiliki pendapatan yang lebih tinggi dapat memenuhi kebutuhan makanan dengan baik maupun nonmakanan. Berikut penjelasan Badan Pusat Statistik (2014) kelompok makanan yang dikonsumsi oleh masyarakat :

\section{Konsumsi Makanan}

a. Padi-padian, seperti: beras, jagung, beras jagung, sorgum, dan nasi aking (sisa nasi konsumsi kemarin yang dikeringkan dan dimasak kembali) .

Padi-padian merupakan makanan pokok bagi masyarakat Widoropayung tidak terkecuali masyarakat penerima BST. Padi-padian yang biasa dikonsumsi meliputi beras, beras jagung, dan nasi aking. Nasi aking ini mereka peroleh dari sisa nasi yang tidak terkonsumsi untuk menghindari kemubadziran sehingga mereka olah kembali menjadi nasi aking, dengan harapan bisa mengalokasikan uang mereka ke konsumsi pemenuhan makanan yang lain misalkan lauk pauk dan sayuran. Selain nasi aking, masyarakat penerima BST juga sering mengkonsumsi beras jagung dicampur dengan beras sebagai makanan pokok mereka. Dengan asumsi hal ini merupakan jalan terbaik menghemat uang dalam pemenuhan makanan pokok ketika pandemi Covid-19 yang menuntut masyarak untuk menjaga imunitas dengan cara tetap menjaga konsumsi makanan bergizi setiap harinya.

b. Umbi-umbian, seperti: sagu dari pohon sagu, gaplek, antara lain gadung, oyek (beras yang dibuat dari singkong), uwi, gembili, gogik, dan sagu dari ketela pohon.

Umbi-umbian juga merupakan salah satu yang dikonsumsi oleh masyarakat Widoropayung penerima BST khususnya. Umbi-umbian yang dimaksud salah satunya singkong. Singkong ini mereka dapatkan dengan harga murah di pasar Rp. 3500/kg. Mereka olah menjadi pengganti lauk salah satunya variasi olahan yang sering disebut dengan "pargedel" . dengan $1 \mathrm{~kg}$ singkong mereka gunakan dalam waktu 3 hari. Tidak hanya dijadikan lauk, mereka olah singkong menjadi makanan ringan keluarga pada saat pandemi Covid-19.
Pada saat pandemi ini pengeluaran uang untuk membeli makanan ringan mereka alokasikan untuk konsumsi yang lebih penting.

c. Ikan segar dan olahan hasil tangkapan laut.

Ikan merupakan makanan mewah para penerima BST disaat pandemi Covi-19. Ikan yang tersedia di pasar Widoropayung diantaranya ikan laut jenis tongkol, layang, teri dll. Pada saat pandemi Covid-19 masyarakat mengeliminasi konsumsi ikan laut yang beli di pasar dari kegiatan konsumsinya. Mereka memilih mengkonsumsi ikan air tawar yang mereka dapatkan dari hasil memancing di sungai. Dengan asumsi lebih segar dan hasil ikan lebih segar dan lebih hemat disaat pandemi Covid-19

d. Daging. (daging kambing, daging ayam, dan daging sapi). Pandemi Covid-19 sangat mempengaruhi pola konsumsi masyarakat, khususnya masyarakat Widoropayung penerima BST. Pola konsumsi masyarakat terhadap makanan pokok terutama daging pada saat Pandemi Covid-19 sangat menurun. Bagi mereka untuk membeli daging sangat sulit karena keterbatasan pendapatan yang mereka dapatkan di saat Pandemi Covid-19. Bagi masyarakat yang memiliki hewan peliharaan seperti ayam lebih memlih menjual ayamnya ke pedagang ayam daripada untuk dikonsumsi sendiri. Sehingga mereka bisa mengalokasikan uangnya untuk hal yang lebih dibutuhkan contohnya, pembelian masker yang harus dilakukan pada saat Pandemi Covid 19.

e. Buah-buahan.

Buah-buahan yang dikonsumsi oleh masyarakat ketika pandemi Covid-19 adalah pepaya. Mereka memenuhi kebutuhan gizi di dalam tubuh dengan mengkonsumsi buah pepaya yang mereka tanam sendiri untuk meningkatkan imunitas diri pada saat pandemi Covid19. Buah papaya bagi masyarakat Desa Widoropayung merupakan buah yang gampang mereka dapatkan dan harga sangat terjangkau. Selain buah pepaya, mereka juga mengkonsumsi buah pisang, buah pisang ini juga sangat gampang didapatkan dan harganyapun juga relatif terjangkau bagi masyarakat Desa Widoropayung.

f. Minyak dan lemak. Minyak tetap dikonsumsi pada saat pandemi Covid-19, namun penggunaan minyak diminimalisir agar pengeluaran untuk membeli minyak dapat dialokasikan ke konsumsi yang lebih penting. Minyak yang digunakan adalah minyak kelapa dalam hal ini sebagai pemenuhan kebutuhan memasak. Minyak goreng kelapa ini merupakan barang yang wajib dimiliki oleh masyarakat. Harga yang cukup terjangkau sekitar Rp 10.000/liter. 
g. Bahan minuman, (gula pasir, coklat, kopi, teh, dll). Masyarakat mengkonsumsi untuk penunjang rasa masakan dan minuman. Kebiasaan masyarakat Desa khususnya Desa Widoropayung adalah mengkonsumsi kopi di pagi hari sebelum berangkat bekerja. Hal ini berdampak pada penggunaan gula juga sebagai hal yang pokok untuk dimiliki selain sebagai memasak. Konsumsi gula mencapai $1 \mathrm{~kg} / \mathrm{minggu}$. Selain gula, kopi juga menjadi barang wajib yang dimiliki. Untuk kopi penggunaannya ketika di pagi hari merupakan minuman wajib menjelang terbitnya matahari. Beda halnya ketika kondisi pandemi Covid19. Kondisi pandemi Covid-19 yang terjadi Indonesia dapat mepengaruhi pola konsumsi masyarakat terhadap minuman kopi (Adiwinata, Sumarwan, \& Simanjuntak, 2021). Masyarakat lebih fokus mengkonsumsi makanan pokok untuk meningkatkan imunitas tubuh

h. Bumbu-bumbuan. Bumbuan dalam sehari-hari sangat diperlukan untuk memberi rasa dan aroma pada masakan. Seluruh masyarakat menggunakan bumbuan dalam kegiatan memasak. Tidak terkecuali masyarakat desa Widoropayung khususnya penerima BST pada saat pandemi Covid-19 tetap mengkonsumsi bumbubumbuan sebagai pelengkap masakan. Bumbuan ini contohnya adalah kunyit, lada, lengkuas, jahe, kencur, bawang merah, bawang putih, ketumbar dll. Untuk tanaman lengkuas, jahe, kunyit,, kencur, masyarakat Desa Widoropayung memiliki inisiatif untuk menanam sendiri di lahan yang terbatas. Dengan harapan mereka bisa mengkonsumsinya tanpa membeli di pasar. Dalam hal ini ketika Pandemi Covid-19 Masyarakat memanfaatkan tanaman tersebut sebagai jamu tradisional untuk meningkatkan daya tahan tubuh ketika pandemi terjadi.

i. Tembakau dan sirih.

Konsumsi tembakau bagi masyarakat Widoropayung penerima BST mayoritas dilakukan oleh masyarakat yang berjenis kelamin laki-laki. Kegiatan konsumsi tembakau pada saat pandemi mengalami penurunan akibat masyarakat lebih memilih menekan konsumsi yang bersifat sekunder . tembakau merupakan produksi lokal masyarakat Desa Widoropayung, namun dalam hal ini mereka menjualnya ke luar daerah seperti Bondowoso, Jember, Probolinggo, dan Lumajang. Ketika Pandemi Covid-19 berlangsung penjualan tembakau menurun dikarenakan kebijakan pemerintah untuk tidak berkerumun dan menjaga jarak dalam hal menanggulangi penyebaran virus Corona.

\section{Konsumsi non makanan}

a. Fasilitas Rumah Tangga,( sewa rumah, biaya PDAM, biaya listrik dan lainnya). Konsumsi pada bagian ini masyarakat cenderung pada konsumsi gas elpigi untuk menunjang kegiatan rumah tangga dalam pemenuhan kebutuhan pokok seperti makan makanan yang bergizi. Gas elpigi yang digunakan adalah tabung hijau dengan harga Rp 18.000/ tabung. Masyarakat mampu menggunakannya dalam kurun waktu 3 minggu sesuai dengan pemakain. Namun, untuk meminimalisir biaya ketika Pandemi Covid-19 masyarakat mengganti konsumsi gas elpigi dengan kayu bakar. Mereka berasusi pemakaian kayu bakar akan mengurangi pengeluaran disaat pandemi berlangsung. Masyarakatmendapatkan kayu bakar ini dengan cara mencari di sekitar rumah, ladang, ataupun tegal.

Dana Anggaran Pendapatan dan Belanja Negara (APBN) dialokasikan oleh pemerintah untuk bantuan sosial seperti subsidi fasilitas listrik (Khaqiqi, Normawati, \& Islami, 2021). Pada saat Pandemi Covid19 pemerintah memberikan subsidi kepada masyarakat Indonesia tidak terkecuali masyarakat Desa Widoropayung. Dengan hal ini mereka tidak dibebankan pembayaran listrik ketika pandemi berlangsung, sehingga uang yang mereka miliki bisa dialokasikan ke hal yang lebih penting contohnya pemenuhan gizi pada makanan sehari-hari.

b. Konsumsi aneka barang dan jasa. (sabun cuci, obatobatan, vitamin, iuran sekolah anak, biaya transportasi). Barang dan jasa yang dikonsumsi masyarakat Desa Widoropayung penerima BST yang disalurkan melalui PT POS meliputi barang dan jasa penunjang utama kebutuhan sehari-hari seperti sabun cuci. Masyarakat mulai lebih menyadari kebersihan diri mulai dari kebersihan rumah dan kebersihan tubuhnya ketika pandemi terjadi. Konsumsi untuk sekolah anak meliputi pembelian kuota internet dalam menunjang pembelajaran daring dampak dari terjadinya pandemi Covid-19. Para orang tua tetap memikirkan bagaimana anak mereka mendapatkan pendidikan tidak terkecuali dalam keadaan pandemi. Dalam konsumsi ini mereka meminimalisisr biaya transportasi selaras dengan kebijakan pemerintah untuk mengurangi kegiatan di luar rumah dalam menekan penularan Virus Corona.

c. Pakaian. Pakaian merupakan kebutuhan primer setiap manusia. Pola konsumsi yang dilakukan oleh masyarakat Desa Widoropayung penerima BST dari pemerintah ketika pandemi hanya meliputi kebutuhan pokok pemenuhan gizi setiap harinya. Pakaian bersih dan layak sangat dibutuhkan tidak terkecuali ketika pandemi terjadi di Indonesia. Hal ini menunjang untuk menciptakan lingkungan yang bersih dan sehat agar terhindar dari virus terutama Virus Covid-19. Pakian yang digunakan merupakan pakaian yang mereka beli ketika sebelum pandemi Covid-19. Mereka berasumsi memakai pakaian tidak harus baru melaikan harus 
bersih apalagi ketika pandemi Covid-19 yang penularannya sangat begitu cepat. Maka dari itu, masyarakat Desa Widoropayung sangat menjaga kebersihan pakaian yang mereka pakai.

d. Biaya pembayaran pajak. Pemerintah Desa Widoropayung dalam hal ini diwakilkan oleh kepala desa, memiliki kebijakan dalam pembayaran pajak PBB. Kebijakannya yaitu memberikan program gratis dalam pembayaran PBB kepada seluruh masyarakat Desa Widoropayung ketika pandemi Covid-19 hal ini dilkukan dengan alasan untuk mengurangi beban masyarakat ketika Pandemi berlangsung yang sangat mempengaruhi dari segala aspek salah satunya adalah yang paling berpengaruh adalah aspek ekonomi.

e. Berbagai macam bentuk upacara adat, pesta perkawinan dan jenis pesta yang lain. Pandemi Covid-19 sangat mempengaruhi kegiatan masyarakat hususnya masyarakat Desa Widoropayung. Hal ini disebabkan oleh kebijakan pemerintah dalam memutuskan mata rantai penyebaran Covid-19 yaitu salah satunya adalah PSBB. Sehingga kegiatan masyarakat yang sekiranya menimbulkan keramaian dan memiliki potensi penyebaran virus lebih cepat tidak diijinkan untuk dilaksanakan. Maka dari itu, kegiatan upacara apapun yang ada di desa hususnya Desa Widoropayung dan perayaan agama yang biasa masyarakat desa lakukan selama pandemi tidak dilakukan seperti pesta pernikahan dan perayaan hari keagamaan.

\section{SIMPULAN}

Berdasarkan hasil penelitian dapat disimpulkan bahwa Pandemi Covid - 19 yang melanda seluruh belahan dunia tidak terkecuali Indonesia sangat berdampak salah satunya dampak terbesar pada perekonomian. Perekonomian yang maju bersumber dari daya beli masyarakat yang tinggi. Untuk mempertahankan hal tersebut, pemerintah Indonesia mengeluarkan bantuan salah satunya berupa Bantuan Sosial Tunai (BST) yang di salurkan oleh PT. POS Indonesia. Pola konsumsi masyarakat Desa Widoropayung penerima BST cenderung lebih ke arah konsumsi kebutuhan pokok seperti makanan dan minuman yang bersih dan bergizi, serta kebutuhan penunjang kesehatan seperti jamu-jamuan, masker, sabun cuci, sabun mandi, agar terhindar dari bakteri atau virus ketika pandemi.

Perlu diadakan penelitian selanjutnya mengenai pola konsumsi masayarakat penerima Bantuan Sosial Tunai lainnya sehingga ditemukan hasil dari keefektifan bantuan sebagai program pemerintah dalam menanggulangi dampak pandemi Covid-19. Keterbatasan penelitian ini adalah hanya dilakukan di Desa Widoropayung dan penerima masyarakat penerima BST yang disalurkan oleh PT. POS Indonesia.

\section{DAFTAR PUSTAKA}

Adiwinata, N. N., Sumarwan, U., \& Simanjuntak, M. (2021). FAKTOR-FAKTOR YANG MEMENGARUHI PERILAKU KONSUMSI KOPI DI ERA PANDEMI COVID-19. Ilmu Keluarga dan Konseling, 189-202.

Arika Bagus P et.al. (2020). Policy Analysis Melindungi Pekerja Rentan di Masa (dan. IGPA MAP FISIPOL UGM dan Forbil Institute.

Badan, S. P. (2014, Maret 1). Badan Pusat Statistik. Dipetik Juni 2, 2021, dari Badan Pusat Statistik: https://www.bps.go.id/indicator/5/55/1/rata-ratakonsumsi-kalori-per-kapita-sehari-menurutkelompok-makanan.html

Dong Y, M. X. (2020). Epidemiology of Covid-19 Among Children in China. American Academy of, 384388.

Huitt, W. (2007). 'Maslow 's Hierarchy of Needs'. European Journal of Social Science, doi:10.1256/wea.73.04

Hutauruk, R. M. (2020). PENGARUH PANDEMI COVID-19 TERHADAP FAKTOR YANG MENENTUKAN PERILAKU KONSUMEN UNTUK MEMBELI BARANG KEBUTUHAN POKOK DI SAMARINDA. Jurnal Riset Inossa, $1-15$.

Iskandar, A. P. (2020). Peran Ekonomi dan Keuangan Sosial Islam Saat Pandemi Covid-19. Jurnal Sosial \& Budaya Syar'i, 625-638.

Juaningsih, I. N. (2020). Optimalisasi Kebijakan Pemerintah dalam penanganan Covid-19 terhadap Masyarakat Indonesi. SALAM: Jurnal Sosial dan Budaya Syar-i, 37.

Kementerian, K. R. (2020, March 20). Info Infeksi Emerging Kementerian Kesehatan R. Diambil kembali dari https://infeksiemerging.kemkes.go.id

Khaqiqi, M., Normawati, R., \& Islami, N. (2021). Analisis Efektifitas Kebijakan Di Tengah Pandemi Covid19 Berbasis Public Policy Evaluation. Dalam U.F. DYCRES, Scientific Paper Academy Tema : Covid-19 (hal. 114). Pekalongan, Jawa Tengah: PT. Nasya Expanding Management.

Larasati, R. A. (2020). POLA KONSUMSI MAHASISWA PULANG KAMPUNG DAN MASYARAKAT. JAMBURA ECONOMIC EDUCATION JOURNAL, 90-99.

Linzey, C. d. (1993). Teori-Teori Holistik. Yogyakarta: Kanisius.

Misno, A. J. (2020). Covid-19. Pustaka Amma Alamiah.

Saragih, B., \& Saragih, F. M. (2020). researchgate.net. Dipetik July 31, 2021, dari researchgate.net: https://www.researchgate.net/

WHO. (2020). Critical Preparedness. Readliness and Response Actions for Covid-19. WHO. 